\title{
PERBEDAAN KEPADATAN TULANG ANTARA PENDERITA AUTIS DAN TIDAK AUTIS
}

\author{
Rizky Amalia, Fillah Fithra Dieny ${ }^{*}$ \\ Program Studi Ilmu Gizi Fakultas Kedokteran Universitas Diponegoro \\ Jl.Dr.Sutomo No.18, Semarang, Telp (024) 8453708, Email : gizifk@ undip.ac.id
}

\begin{abstract}
ABSTRAK
Latar Belakang: Penderita autis memiliki beberapa gangguan khas, antara lain gangguan perilaku, gangguan penyerapan, serta gangguan makan. Salah satu cara untuk mengurangi gangguan perilaku penderita autis adalah melakukan diet bebas gluten bebas kasein (BGBC). Penerapan diet BGBC yang tidak tepat pada penderita autis menyebabkan defisiensi asupan zat gizi seperti vitamin D dan kalsium yang mengakibatkan penderita autis lebih berisiko memiliki kepadatan tulang rendah dibandingkan dengan anak yang tidak autis.

Tujuan: Menganalisis perbedaan kepadatan tulang antara penderita autis dan tidak autis

Metode: Penelitian observasional dengan desain penelitian case control dengan subjek 20 penderita autis dan tidak autis 10-19 tahun yang diambil secara consecutive sampling. Data yang diambil asupan vitamin D dan kalsium, dan nilai kepadatan tulang. Penilaian asupan vitamin D dan kalsium diperoleh melalui formulir FFQ (Food Frequency Semi Quantitative) dan nilai kepadatan tulang menggunakan z-score quantitative ultrasound bone densitometry. Analisis bivariat menggunakan uji Independent T-Test

Hasil: Rerata z-score kepadatan tulang penderita autis lebih rendah $(-1,47 \pm 0,91)$ dibandingkan dengan anak tidak autis $(0,32 \pm 0,53)$. Kepadatan tulang yang rendah (z-score < -2) hanya ditemukan pada kelompok penderita autis (35\%). Pada kedua kelompok sebagian besar mempunyai asupan vitamin $D$ dan kalsium rendah. Terdapat perbedaan kepadatan tulang antara kelompok penderita autis dan tidak autis $(p=0,00)$
\end{abstract}

Simpulan: Terdapat perbedaan kepadatan tulang antara penderita autis dan tidak autis

Kata kunci: autis; kepadatan tulang

\begin{abstract}
Background: autism have some typical disorders, such as behavior, eating disorders, and malabsorption. One of suggested diet to alleviate the behaviour disorder in autism is gluten-free casein-free (GFCF) diet. The application of inappropriate GFCF diet cause insufficient vitamin $D$ and calcium intake which results in autism have higher risk to have lower bone density than non autism.

Objective: the aim of this study was to analyze the difference of bone density between autism and non autism

Method: observational research with casae control design with 20 subjects autism and 20 subject non autism who were selected by cosecutive sampling. The data were vitamin $D$ and calcium intake, and bone density score. Vitamin $D$ and calsium intake measured by FFQ (Food Frequency Semi Quantitatve) formulir, and measurement of bone mass used quantitative ultrasound bone densitometry. Bivariat analysis using Independent T-test.

Result: Mean of z-score bone density in autism were lower $(-1,47 \pm 0,91)$ than non autism $(0,32 \pm 0,53)$. Low bone density (<-2 z-score) only found in autism group (35\%). Vitamin D and calcium intake was low in both groups. There was significant difference in bone density between childrem with autism and non autism $(p=0,00)$

Conclusion: there was difference in bone density between autism and non autism
\end{abstract}

Keyword: autism; bone density

\section{PENDAHULUAN}

Kepadatan tulang pada usia anak dan remaja adalah penentu kesehatan tulang pada saat usia dewasa dan menjadi risiko osteoporosis, tetapi di sisi lain terjadi peningkatan kasus osteoporosis dini (osteopoenia) pada usia muda. Hasil penelitian yang dulakukan di beberapa kota oleh Pusat Penelitian dan Pengembangan Gizi dan Makanan Depkes RI menujukkan bahwa osteopenia telah menyerang usia muda yang berumur di bawah 25 tahun dengan prevalensi $37,1 \%{ }^{1}$

Osteoporosis ditandai dengan menurunnya kekuatan tulang dan meningkatnya kerapuhan yang disebabkan oleh kepadatan tulang yang rendah. Pencegahan terjadinya kepadatan tulang yang rendah dapat dilakukan dengan memaksimalkan massa tulang pada saat puncak pertumbuhan (peak bone mass) yang ditentukan pada masa anak-anak dan remaja. Terjadinya kepadatan tulang rendah pada masa anakanak dan remaja dipengaruhi oleh faktor genetik, status gizi, asupan zat gizi baik makro maupun mikro, serta aktifitas fisik. ${ }^{2}$ Zat gizi mikro yang penting bagi kesehatan tulang diantaranya adalah vitamin D dan 
kalsium. Seperti yang kita ketahui bahwa vitamin D dan kalsium berguna untuk menjaga kesehatan dan kepadatan mineral tulang serta mencegah terjadinya osteoporosis dan patah tulang pada usia dewasa.

Salah satu kelompok anak yang berisiko mengalami defisiensi vitamin D dan kalsium yang dapat berpengaruh terhadap kepadatan tulang adalah penderita autis. Autis adalah gangguan perkembangan anak yang sangat mempengaruhi cara berinteraksi dan berkomunikasi dengan orang-orang di sekitar mereka. ${ }^{3}$ Tanda- tanda autisme mulai nampak sebelum usia 3 tahun dan angka kejadian pada laki-laki 5 kali lebih banyak dibandingkan pada perempuan. ${ }^{4}$ Jumlah penderita autis di Amerika meningkat setiap tahunnya. Tahun 2012, jumlah penderita autis meningkat menjadi 2\% dibandingkan tahun 2007 yang jumlahnya hanya $1,16 \% .{ }^{5}$ Prevalensi autis di dunia saat ini mencapai `5-10 kasus per 10.000 anak atau sekitar 0,15-0,20\%. Jika angka kelahiran di Indonesia 6 juta per tahun maka jumlah penderita autis di Indonesia bertambah $0,15 \%$ atau 6.900 anak pertahunnya. ${ }^{6}$

Penelitian pada tahun 2012 menunjukkan bahwa penderita autis lebih berisiko mengalami kepadatan tulang yang rendah dibandingkan dengan anak normal. Risiko tingginya kepadatan tulang rendah pada penderita autis disebabkan karena asupan beberapa zat gizi seperti vitamin D dan kalsium yang rendah. ${ }^{2}$

Rendahnya asupan vitamin D dan kalsium pada penderita autis salah satunya disebabkan karena diet Bebas Gluten dan Bebas Casein (BGBC), di mana terjadi pembatasan konsumsi beberapa makanan yang mengandung protein gluten yang terdapat pada gandum serta melakukan pembatasan terhadap makanan yang mengandung protein casein yang banyak terdapat pada susu dan olahannya yang merupakan makanan sumber vitamin D dan kalsium. Tujuan diet BGBC adalah untuk mengurangi gangguan perilaku, memenuhi kebutuhan gizi, dan meningkatkan kualitas hidup penderita autis. ${ }^{6}$ Penelitian tahun 2012, asupan vitamin D pada penderita autis adalah 25\% dari dietary reference intake (DRI) yang disarankan dan asupan kalsium adalah $75 \%$ DRI. ${ }^{4}$ Rendahnya asupan vitamin D dan kalsium terjadi karena penerapan diet BGBC pada penderita autis belum dilakukan dengan benar, yaitu mengganti makanan yang dihindari penderita autis dengan bahan makanan lain yang mengandung tinggi kalsium dan vitamin D.

Selain karena penerapan diet BGBC yang tidak tepat, asupan vitamin D dan kalsium yang rendah disebabkan karena penderita autis mengalami gangguan yang khas, seperti gangguan makan dan gangguan penyerapan. Penelitian -penelitian yang sudah dilakukan sebelumnya mengatakan bahwa penderita autis adalah seorang picky eater atau pemilih makanan. Sebanyak $69 \%$ penderita autis enggan untuk mencoba makanan baru, 60\% hanya memakan beberapa jenis makanan saja atau kurang dari 20 jenis makanan. Disebutkan bahwa pemilihan makanan yang dilakukan oleh penderita autis tergantung pada tekstur makanan (69\%), penampilan $(58 \%)$, rasa $(45 \%)$, aroma $(36 \%)$, dan suhu $(69 \%)$. ${ }^{7}$ Gangguangangguan tersebut disebabkan bukan karena buruknya nafsu makan, tetapi karena penderita autis hanya mau makan makanan yang disukai saja.

Selain karena rendahnya asupan vitamin D dan kalsium, rendahnya kepadatan tulang penderita autis disebabkan oleh adanya gangguan pada sistem pencernaan seperti terjadinya malabsorpsi. Gangguan penyerapan yang terjadi disebabkan karena berlubangnya mukosa usus yang menyebabkan makanan tidak dapat dipecah sempurna sehingga zat gizi tidak dapat di absorpsi dengan baik. ${ }^{8}$ Disamping itu faktor aktifitas fisik/olah raga dan paparan sinar matahari yang kurang juga menyebabkan kepadatan tulang yang rendah pada penderita autis. Dari faktor-faktor tersebut penulis tertarik untuk mengetahui perbedaan kepadatan tulang penderita autis dan tidak autis.

\section{METODE}

Penelitian dilakukan pada siswa siswi di SLBN Semarang dan siswa-siswi di luar SLBN Semarang. pada bulan Oktober-November 2013. Penelitian ini merupakan penelitian observasional dengan rancangan case control pada penderita autis dan tidak autis. Kelompok penderita autis adalah siswa-siswi yang terdiagnosis autis berdasarkan informasi/data dari pihak sekolah yang dibuktikan dengan surat keterangan dokter.

Pengambilan subjek dilakukan dengan metode consecutive sampling untuk mendapatkan subjek penelitian sebesar 40 subjek yang sesuai dengan kriteria inklusi, yang terdiri dari 20 subjek kelompok penderita autis dan 20 subjek kelompok tidak autis. kriteria inklusi penelitian seperti usia 10-19 tahun serta tidak sedang mengkonsumsi obat-obatan yang dapat mengganggu metabolisme kalsium dan vitamin D. 
Alur penelitian ini adalah penderita autis yang bersedia berpartisipasi dan diizinkan oleh orang tua dengan menandatangani informed consent kemudian diukur berat badan, tinggi badan, dan kepadatan tulangnya. Setelah selesai melakukan pengukuran terhadap 20 subjek penderita autis, dilakukan wawancara kepada orang tua/wali. Hal yang sama juga dilakukan kepada kelompok tidak autis sesuai dengan kriteria inklusi dan matching terhadap umur dan jenis kelamin

Variabel terikat penelitian ini adalah kepadatan tulang sedangkan variabel bebas dalam penelitian ini adalah status autis. Kepadatan tulang merupakan gambaran/nilai dari hasil pengukuran tulang tumit (calcanes) yang dinyatakan dengan standar deviasi (z-score) dengan menggunakan alat bone densitometry metode Quantitative Ultrasound (QUS). Kategori kepadatan tulang dibagi menjadi kepadatan tulang rendah $<-2$ SD dan kepadatan tulang normal $\geq-2$ SD. ${ }^{9}$

Data karakteristik subjek meliputi jenis kelamin dan usia yang diperoleh melalui kuisioner yang diisi oleh orang tua responden bagi penderita autis dan diisi sendiri bagi anak tidak autis yang didampingi enumerator. Pengukuran berat badan menggunakan timbangan injak ketelitian $0,01 \mathrm{~kg}$ dan tinggi badan diukur dengan menggunakan microtoise ketelitian $0,1 \mathrm{~cm}$. Hasil data antropometri diolah menjadi data IMT yang kemudian dibandingkan dengan umur untuk mendapatkan kategori status gizi untuk usia 5-19 tahun. Kategori yang digunakan adalah sangat kurus yaitu kurang dari -3 SD, kurus antara -3 SD sampai dengan -2 SD, normal antara -2 SD sampai 1 SD, gemuk antara 1 SD - 2 SD, dan obesitas lebih dari 2 SD.

Asupan vitamin D dan kalsium merupakan jumlah rerata asupan vitamin D dan kalsium dari berbagai macam makanan, minuman, dan suplemen yang dikonsumsi setiap hari. Asupan vitamin D dan kalsium diperoleh melalui formulir Food Frequency Semi Quantitative (FFQ) yang diisi sendiri oleh responden yang tidak autis dan diisi oleh orang tua bagi penderita autis. Data tersebut kemudian dibandingkan dengan Angka Kecukupan Gizi (AKG) dan dikategorkian menjadi kurang (<80\% AKG), normal (80-100\% AKG), dan lebih (>100\% AKG). ${ }^{10}$ AKG vitamin D untuk usia 10-12 tahun, 13-15 tahun, 16-18 tahun, dan 19-29 tahun baik laki-laki dan perempuan adalah 5 $\mu$ g. Sedangkan AKG kalsium untuk usia 10-12, 13-15, 16-18 tahun baik laki-laki dan perempuan adalah $1000 \mathrm{mg}$, dan $800 \mathrm{mg}$ untuk AKG kalsium kelompok umur 19-29 tahun. ${ }^{11}$

Data yang diperoleh kemudian diolah dan dianalisis untuk mengetahui perbedaan kepadata tulang antara penderita autis dengan tidak autis menggunakan uji Independent t-Test yang sebelumnya diuji normalitas data menggunakan Shapiro Wilk.

\section{HASIL PENELITIAN}

\section{Karakteristik Subjek Penelitian}

Berdasarkan hasil pengambilan data yang dilakukan didapatkan data kepadatan tulang rendah hanya ditemukan pada penderita autis $(35 \%)$. Data status gizi menunjukkan sebagian besar pada kedua kelompok memiliki status gizi normal.

Tabel 1. Karakteristik subjek penelitian berdasarkan kepadatan tulang, kategori status gizi, serta asupan vitamin D dan kalsium

\begin{tabular}{lcccc}
\hline variabel & \multicolumn{2}{c}{ Autis $(\mathrm{n}=20)$} & \multicolumn{2}{c}{ Tidak autis $(\mathrm{n}=20)$} \\
\cline { 2 - 6 } & $\mathrm{n}$ & $\%$ & $\mathrm{n}$ & $\%$ \\
\hline Kepadatan Tulang & 13 & 65 & 20 & 100 \\
Normal & 7 & 35 & - & - \\
Rendah & 1 & 5 & - & - \\
\hline Kategori status gizi & 2 & 10 & 2 & 5 \\
Sangat kurus & 14 & 70 & 14 & 70 \\
Kurus & 2 & 10 & 3 & 15 \\
Normal & 1 & 5 & 1 & 5 \\
Gemuk & & & & \\
Obesitas & 14 & 70 & 10 & 50 \\
\hline Kategori asupan vitamin D & 4 & 20 & 1 & 5 \\
Kurang & & &
\end{tabular}




\begin{tabular}{lcccl} 
Lebih & 2 & 10 & 9 & 45 \\
\hline Kategori asupan kalsium & & & & \\
Kurang & 19 & 95 & 15 & 75 \\
Normal & - & - & 1 & 5 \\
Lebih & 1 & 5 & 4 & 20 \\
\hline
\end{tabular}

Asupan vitamin D pada kedua kelompok sebagian besar masuk kategori kurang, namun dibandingkan dengan kelompok tidak autis, asupan vitamin $\mathrm{D}$ dan kalsium kategori kurang pada kelompok penderita autis jauh lebih banyak, yaitu 14 anak (70\%). Begitu juga dengan asupan kalsium di mana kedua kelompok sebagian besar masuk kategori kurang, namun kelompok autis terdapat lebih banyak anak dengan asupan kalsium kurang yaitu 19 anak (95\%).

Perbedaan kepadatan tulang, asupan vitamin D dan kalsium pada kedua kelompok

Tabel 2. nilai rerata, standar deviasi beberapa variabel

\begin{tabular}{llll}
\hline \multirow{2}{*}{ Variabel } & Autis $(\mathrm{n}=20)$ & Tidak Autis $(\mathrm{n}=20)$ & \multirow{2}{*}{ P value } \\
\cline { 2 - 3 } & Mean \pm SD & Mean \pm SD & \\
\hline z-score kepadatan tulang & $-1,47 \pm 0.91$ & $0,32 \pm 0,53$ & 0,00 \\
Asupan Vitamin D $(\mu \mathrm{g})$ & $4,24 \pm 5,17$ & $5,55 \pm 4,22$ & 0,88 \\
Asupan Kalsium $(\mathrm{mg})$ & $593,2 \pm 923,3$ & $643,2 \pm 565,4$ & 0,42 \\
\hline
\end{tabular}

Tabel 2 menunjukkan terdapat perbedaan yang signifikan kepadatan tulang $(p=0,00)$ antara penderita autis dan tidak autis, sedangkan asupan vitamin D dan kalsium tidak terdapat perbedaan antara kelompok autis dan tidak autis $(\mathrm{p}>0,05)$. Nilai rerata $\mathrm{z}$-score kepadatan tulang pada penderita autis lebih rendah $(-1,47 \pm 0.91)$ dibanding dengan tidak autis $(0,32 \pm 0,53)$.

\section{PEMBAHASAN}

\section{Karakteristik Subjek Penelitian}

Status gizi (IMT/U) pada kedua kelompok baik kelompok autis maupun kelompok tidak autis sebagian besar (70\%) masuk kategori normal. Jumlah penderita autis dan tidak autis dengan status gizi kurus, gemuk dan obesitas hampir sama. Namun kelebihan berat badan pada saat usia muda harus lebih diwapadai terutama jika sampai kategori obesitas, karena akan menetap sampai usia dewasa. Kelebihan berat badan dan obesitas pada anak meningkatkan risiko beragai penyakit degeneratif, seperti kanker, kardiovaskular, diabetes, masalah orthopedic, dan sleep apnea. ${ }^{12}$

Sebuah penelitian yang dilakukan di Amerika menunjukkan prevalensi obesitas pada penderita autis lebih besar $(30,4 \%)$ dibandingkan dengan kelompok tidak autis $(23,6 \%)$. Penderita autis memiliki aktifitas fisik yang berbeda dan juga pola makan yang unik yang dapat menyebabkan obesitas. Penderita Autis memiliki gangguan motorik yang mempengaruhi kemampuan mereka untuk berpartisipasi dalam kegiatan olahraga. Gangguan motorik tersebut berupa rendahnya ketrampilan gerak, ketidakstabilan gerak, dan kelemahan pada otot. ${ }^{13-14}$

Selain itu penderita autis mengalami rendahnya aktifitas fisik karena gangguan dalam bersosialisasi yang membatasi partisipasi dalam kegiatan dengan teman-temannya. ${ }^{15}$ Terkait dengan gangguan makan yang dialami penderita autis, obesitas disebabkan karena penderita autis tidak dapat mengenal rasa lapar dan kenyang. Berdasarkan hasil wawancara diketahui bahwa penderita autis tidak akan berhenti makan apabila tidak diingatkan oleh orang tua ataupun pengasuhnya. Penderita autis juga akan memakan makanan yang ada dihadapannya walaupun tidak merasa lapar.

\section{Perbedaan Asupan Vitamin D dan Kalsium antara Penderita autis dan Tidak Autis}

Faktor penyebab kepadatan tulang rendah dibedakan menjadi faktor yang tidak dapat diubah dan faktor yang dapat diubah. Faktor yang tidak dapat diubah seperti genetik (keturunan, ras, dan hormon) jenis kelamin, dan usia. Sedangkan faktor yang dapat diubah antara lain status gizi, asupan zat gizi, dan kebiasaan olah raga. ${ }^{16}$

Wanita Asia memiliki risiko osteoporosis lebih besar dibandingkan dengan ras non-kauskasian. Hal ini disebabkan karena asupan kalsium wanita Asia lebih rendah. Sekitar 50\% total massa tulang pada wanita dewasa ditentukan selama pubertas, sedangkan pria hanya $20 \% .{ }^{17}$ Pada ras kaukasian, maksimal 
peningkatan massa tulang terjadi antara usia 11 dan 14 tahun pada wanita sedangkan pria antara usia 13 dan 17 tahun. $^{18}$

Asupan terkait kepadatan tulang seperti vitamin D dan kalsium merupakan faktor yang dapat diubah dan penting untuk diperhatikan. Pada kedua kelompok sebagian besar subjek memiliki asupan vitamin D dan kalsium kurang $(<80 \%$ AKG), di mana AKG vitamin D untuk remaja laki-laki maupun perempuan usia 10-18 tahun adalah 5 $\mu \mathrm{g} / \mathrm{hari}$ dan AKG kalsium adalah $1000 \mathrm{mg} / \mathrm{hari}$. Hasil penelitian menunjukkan tidak ada perbedaan asupan vitamin D dan kalsium pada kedua kelompok, namun menurut rerata menujukkan bahwa rerata asupan vitamin D dan kalsium pada penderita autis lebih rendah dibandingkan kelompok tidak autis.

Defisiensi asupan vitamin D dan kalsium berkaitan dengan diet bebas-gulten dan bebas-casein (BGBC) yang diterapkan oleh penderita autis. Diet BGBC diterapkan bertujuan untuk mengontrol gangguan perilaku pada anak autis. Diet (BGBC) membatasi konsumsi makanan yang mengandung gluten dan kasein. Makanan yang mengandung gluten terdapat pada makanan yang berbahan dasar dari gandum, seperti roti, mie, biskuit. Sedangkan makanan yang mengandung kasein adalah makanan yang berasal dari susu hewan dan olahannya seperti keju, yogurt, mentega (butter), kefir, dan lainnya.

Sekitar $90 \%$ anak autis alergi terhadap susu sapi dan gandum-ganduman. Susu sapi mempunyai protein yang disebut casein, sedangkan protein dari gandum disebut gluten. Kedua jenis protein ini agak sulit dicerna karena terdiri dari rangkaian asam amino yang panjang. Jika pencernaan terganggu maka rangkaian asam amino tersebut tidak lepas total, dan masih terdapat asam amino yang bergandengan, yang disebut peptida. Peptida inilah yang diduga menjadi penyebab terjadinya gangguan perilaku berupa hiperaktivitas pada penderita autis. ${ }^{19}$

Ada beberapa jenis diet yang dianjurkan untuk penderita autis seperti diet BGBC, diet gula, diet yeast/ragi, dan diet zat aditif. Diet BGBC paling banyak dianjurkan karena dapat meningkatkan kemampuan berbahasa dan mengurangi gangguan perilaku penderita autis. ${ }^{3,19}$ Penelitian di Bandung melaporkan bahwa sebanyak $85 \%$ orangtua yang tidak patuh dalam menjalankan diet BGBC berdampak pada terjadinya gangguan perilaku anak mereka dibandingkan pada anak autis yang orangtuanya patuh menjalankan diet. ${ }^{20}$

Apabila diet BGBC tidak diterapkan dengan tepat dapat menyebabkan defisiensi zat gizi makro maupun zat gizi mikro, salah satunya adalah defisiensi vitamin $\mathrm{D}$ dan kalsium yang baik bagi pertumbuhan anak. Penerapan diet BGBC dikatakan tidak tepat apabila tidak mengganti makanan yang dihindari dengan makanan yang mengandung tinggi vitamin D dan kalsium seperti ikan, brokoli, kacangkacangan.

Penelitian ini hanya 4 anak (20\%) yang melakukan diet BGBC. Penderita autis lainnya hanya melakukan pembatasan baik frekuensi makan dan kuantitas makanan yang mengandung gluten dan kasein. Dari keempat subjek tersebut 50\% (2 anak) yang mengalami asupan vitamin D kurang dan 75\% (3 anak) yang asupan kalsium kurang. Dari 4 subjek kelompok autis yang melakukan diet BGBC dan tidak mengalami defisiensi vitamin D dan kalsium hanya 1 orang, tetapi subjek tersebut mengalami kepadatan tulang rendah. Hasil ini kemungkinan dapat disebabkan karena aktifitas fisik dan paparan sinar matahari yang kurang serta hasil FFQ asupan protein dan fosfor yang termasuk dalam kategori lebih.

Rendahnya asupan vitamin D dan kalsium pada penderita autis ternyata bukan disebabkan karena penerapan diet BGBC, karena hanya 4 anak yang melakukan diet BGBC. Defisiensi asupan vitamin D dan kalsium pada penderita autis disebabkan karena faktor lain seperti terjadinya gangguan makan yang dialami penderita autis. Gangguan makan yang terjadi berupa memilih makanan hanya yang mereka kehendaki dan sukai saja sehingga membuat asupan makanan menjadi terbatas. Menurut sebuah studi tahun 2000 sebanyak $73 \%$ penderita autis yang memilih-milih makanan memiliki nafsu makan yang lebih terhadap makanan yang disukai. Hal ini menujukkan bahwa memilih makanan yang terjadi bukan karena nafsu makan yang buruk. ${ }^{21}$

Penelitian yang dilakukan di Jogjakarta dan Jepang pada tahun 2012 menunjukkan bahwa penolakan terhadap makanan baru dan hanya mengkonsumsi makanan yang sama dikarenakan karena perilaku anak autis yang khas, yaitu melakukan pengulangan, tidak fokus dan tidak tertarik terhadap sesuatu. ${ }^{22}$ Selain itu gangguan sensori juga terjadi pada indera perasa sehingga akan mengganggu aktivitas makannya. Akibatnya banyak anak autis bahkan hingga dewasa hanya bisa mengkonsumsi sedikit jenis makanan. Hal ini dikarenakan indera perasa mereka hanya bisa menikmati tekstur dan rasa tertentu. ${ }^{19}$ 
Anak autis dengan gangguan sensori yang parah tidak dapat mencium aroma masakan tertentu. Hal ini membuat anak autis tidak pernah tergiur makanan. Bahkan pada beberapa kasus anak autis tidak merasakan rasa lapar dan kenyang. Memilih-milih makanan merupakan masalah serius karena berkaitan dengan defisiensi zat gizi sebagai hasil dari terbatasnya asupan makan. ${ }^{7}$

Asupan vitamin D dan kalsium rendah juga ditemukan pada anak tidak autis/normal. Penemuan ini sejalan dengan penelitian yang dilakukan pada remaja di Ungaran pada tahun 2012 tentang rendahnya asupan kalsium dan vitamin D. ${ }^{23}$ Penelitian tersebut menunjukkan $70,8 \%$ remaja mengalam asupan kalsium kurang dengan rata-rata $622,74 \mathrm{mg} /$ hari, tidak berbeda jauh dengan penelitian ini yaitu 643,2 $\mathrm{mg} /$ hari. Asupan vitamin D dan kalsium kurang pada anak tidak autis terjadi karena rendahnya konsumsi makanan yang mengandung kalsium dan vitamin D seperti susu sapi, keju, yogurt, ikan laut, serta kacangkacangan seperti tempe, tahu, dan susu kedelai. Rendahnya asupan vitamin D dan kalsium dipengaruhi oleh perilaku makan.

Perilaku makan yang merupakan gaya hidup yang dipengaruhi oleh lingkungan. Lingkungan sekolah mempengaruhi asupan vitamin D dan kalsium karena sebagian besar aktifitas kelompok tidak autis dilakukan di sekolah. Makanan bergizi sebaiknya disediakan oleh pihak sekolah (kantin) untuk memenuhi kebutuhan asupan zat gizi terutama vitamin D dan kalsium sehari-hari. Selain lingkungan, faktor sikap dan perilaku makan juga berpengaruh terhadap asupan vitamin D dan kalsium anak dan remaja.

Penelitian yang dilakukan di Ungaran menunjukkan sikap anak tidak autis terhadap makanan yang mengandung kalsium sebagian besar masuk kategori sesuai. Sikap tidak sesuai dikarenakan subjek tidak peduli terhadap pentingnya kalsium bagi tubuh dan juga beranggapan bahwa olahraga tidak berpengaruh terhadap penyerapan kalsium. Selain itu perilaku makan juga berpengaruh terhadap rendahnya asupan vitamin D dan kalsium pada kelompok anak tidak autis. Perilaku makan yang tidak benar dikaitkan dengan menolak mengkonsumsi susu dan olahannya dengan alasan sumber makanan tersebut menyebabkan diri mereka menjadi gemuk. ${ }^{23}$ Selain itu pendidikan orang tua juga berpengaruh terhadap kualitas dan kuantitas konsumsi makanan sumber vitamin D dan kalsium.

\section{Perbedaan Kepadatan Tulang antara Penderita autis dan Tidak Autis}

Hasil penelitian menunjukkan bahwa terdapat perbedaan yang signifikan kepadatan tulang antara penderita autis dan tidak autis $(p=0,00)$. Rerata $z$-score kepadatan tulang pada penderita autis lebih rendah dibandingkan dengan anak tidak autis yaitu $-1,47 \pm 0,91$ pada penderita autis dan $0,32 \pm 0,53$ pada kelompok tidak autis. Kepadatan tulang rendah hanya ditemukan pada subjek kelompok penderita autis yaitu sebanya 7 anak (35\%), sedangkan pada kelompok anak tidak autis tidak ditemukan kepadatan tulang rendah. Hal tersebut sesuai dengan penelitian sebelumnya yang dilakukan di Ohio tahun 2013 bahwa terdapat perbedaan kepadatan tulang antara penderita autis dan tidak autis. Penderita autis lebih berisiko mengalami kepadatan tulang rendah dibandingkan dengan anak normal. ${ }^{2}$

Kepadatan tulang rendah disebabkan karena defisiensi asupan vitamin D dan kalsium. ${ }^{16}$ Tetapi pada penelitian ini asupan vitamin D dan kalsium pada kedua kelompok sama-sama rendah dan hanya kelompok penderita autis yang mengalami kepadatan tulang rendah. Keadaan defisiensi asupan vitamin D dan kalsium diperparah dengan adanya gangguan penyerapan yang dialami penderita autis. Gangguan penyerapan yang terjadi berupa lubang-lubang pada mukosa usus penderita autis yang menyebabkan meningkatnya permeabilitas usus, yang dikenal dengan leaky gut. Karena kondisi tersebut menyebabkan zat-zat gzi tidak dapat tercerna dengan baik. Selain itu pada penderita autis terjadi atrofi pankreas. Atrofi pankreas menyebabkan terjadinya defisiensi enzim pencernaan dan timbul gangguan pencernaan sehingga menyebabkan malabsorpsi dan malnutrisi. ${ }^{24}$

Selain gangguan-ganguan khas pada penderita autis, kurangnya paparan sinar matahari juga dapat menjadi penyebab rendahnya konsentrasi vitamin D dalam darah. Paparan sinar matahari pagi dan sore memicu kulit untuk membentuk vitamin $\mathrm{D}_{3}$. Dalam mineralisasi tulang, sel osteoblas (sel pembentuk tulang) membutuhkan kalsium sebagai bahan dasar dan hormon kalsitriol. Kalsitriol berasal dari vitamin $\mathrm{D}_{3}$ kulit dan vitamin $\mathrm{D}_{2}$ yang berasal dari makanan (mentega, keju, telur, ikan). ${ }^{25}$

Penderita autis jarang terkena paparan sinar matahari, karena aktifitas mereka sebagian besar dilakukan di dalam ruangan baik ketika berda di sekolah, tempat terapi, maupun rumah. Penderita autis umumnya tidak melibatkan diri pada lingkungan sosial dan hanya menghabiskan waktu di rumah untuk bermain video game, komputer, dan kegiatan lainnya yang dilakukan di dalam ruangan. ${ }^{13}$ Berdasarkan hasil wawancara diketahui bahwa penderita autis beraktifitas di luar ruangan hanya saat pelajaran olah 
raga berlangsung yang dilaksanakan 2 kali dalam satu minggu. Olah raga atau aktifitas fisik juga sangat berpengaruh terhadap kepadatan tulang anak. Sebuah penelitian di Amerika Serikat tentang aktifitas fisik pada anak dan remaja autis ditemukan bahwa penderita autis memiliki aktifitas fisik yang lebih rendah dibandingkan dengan rekan-rekan seusianya. ${ }^{26}$

\section{SIMPULAN}

Kepadatan tulang rendah hanya ditemukan pada penderita autis (35\%). Asupan kalsium dan vitamin D dan kalsium pada kedua kelompok sebagian besar masuk kategori kurang, namun asupan penderita autis lebih rendah dibandingkan dengan anak tidak autis. Terdapat perbedaan signifikan kepadatan tulang antara penderita autis dan tidak autis.

\section{SARAN}

Kepadatan tulang rendah ditemukan pada kelompok penderita autis. Asupan zat gizi terkait kepadatan tulang (diantaranya vitamin D dan kalsium) serta aktifitas fisik dan paparan sinar matahari perlu diperhatikan guna mencegah terjadinya kepadatan tulang rendah pada anak autis. Mengkonsumsi bahan makanan selain susu yang kaya kalsium seperti ikan duri lunak, brokoli, dan kacang-kacangan. Selain itu mengkonsumsi makanan yang membantu penyerapan kalsium (yang mengandung protein, vitamin D, gula/gula alkohol) diantaranya daging, ikan salmon, udang, susu kedelai, dan tahu, penting bagi penderita autis yang menerapkan diet BGBC.

\section{UCAPAN TERIMA KASIH}

Puji syukur penulis panjatkan kepada Allah SWT atas limpahan rahmat-Nya. Penulis mengucapkan terima kasih kepada Kepala Sekolah, siswa-siswi dan orang tua murid SLB N Semarang, SMK N 8 Semarang, SMP N 10 Semarang dan Manager Area Semarang PT. BAYER beserta tim atas kerjasama, kebaikan, dan partisipasinya dalam penelitian ini.

\section{DAFTAR PUSTAKA}

1. Hardinsyah, Damayanthi Evy, Zulfanti Wirna. Hubungan konsumsi susu dan kalsium dengan densitas tulang dan tinggi badan remaja. Jurnal Gizi dan Pangan, 2008; 3(1):43-48

2. Neumeyer AM, Gates Amy, Ferrone Christine, Lee Hang, Misra Madhusmia. Bone density in peripubertal boys with autism spectrum disorders. Journal of Autism and Developmental Disorders 2013; Volume 43:1623-1629

3. Hsu Chia-Lin, Lin Delmar CY, Chen Chia-Lin, Wang Chin-Man, Wong Alice MK.. The effect of a gluten and casein-free diet in children with autism: a case report. Chang Gung Med J 2009; 32:459-465

4. Moore Erin, Crook Tina, James Jill, Gonzales Dana, Hakkak Reza. Nutrient intake among children with autism. J. Nutr Disorders Ther 2012; 2:3

5. Blumberg SJ, Bramlett MD, Kogan MD, Schieve LA, Jones JR. Changes in prevalence of parent-reported autism spectrum disorder in school-aged U.S. children: 2007 to 2011-2012. National Helath Statistics Report 2013; 65:1-11

6. Mashabi NA, Tajudin NR. Hubungan antara pengetahuan gizi ibu dengan pola makan penderita autis. Makara, Kesehatan 2009; $13: 84-86$.

7. Cermak SA, Curtin Carol, Bandini LG. Food selectivity and sensory sensitivity in children with autism spectrum disorders. Journal of the American dietetic Association 2009; $110: 238-246$.

8. Matthews Julie. Diet for autism: the science healing of traditional diets for autism. The Autism File Global Issue 2012; 39: 72-79

9. Anderson JJB. Nutrition and bone health. In : Mahan K, Escott-Stump S, Editors. Krause's Food, Nutrition And Diet Theraphy. $12^{\text {th }}$ Edition. Philadelphia : Saunders; 2008. p.614-33.

10. Widajanti L. Buku petunjuk praktikum survei konsumsi gizi. Semarang. Bagian Prodi Magister Gizi Masyaraka Program Pascasarjana UNDIP. 2007

11. Departemen Kesehatan RI. Angka kecukupan gizi 2004 bagi orang Indonesia. Available at http://gizi.depkes.go.id/download/AKG2004.pdf

12. Curtin Carol, Bandini LG, Perrin EC, Tybor DJ, Must Aviva. Prevalence of overweight in children and adolescents with attention deficit hyperativity disorder and autism spectrum disorders: a chart review. BioMed Central Pediatrics 2005; 5:48

13. Baranek GT. Efficasy of sensory and motor intervensions for children with autism. J Autism Dev Disord 2002; $32: 387-422$ 
14. Dewey D, Cantell M, Crawford SG. Motor and gestural performance in children with autism spectrum disorders, developmental coordination disorder, and/or attention deficit hyperactivity disorder. J Int Neuropsychol Soc 2007. 13: 246-256

15. Dziuk MA, Gldley Larson JC, Apostu A, Mahone EM, Denckla MB, Motostofsky SH. Dyspraxia in autism: association with motor, social, and communicative deficits. Dev Med Child Neurol 2007. 49: 734-739

16. Daly RM, Petit MA. Optimizing bone mass and strength: the role of physical activity and nutrition during growth. Switzerland: Karger. 2007: 50-61

17. Janice LT, Melinda MM, Ans Linda A. The Science Of Nutrition $2^{\text {nd }}$ ed. USA: Pearson Education, Inc 2008. $p$ 410-437.

18. JM Pettifor, A Prentice, and P Cleaton-Jones. The Skeletal System. In: Michael JG, Ian AM, and Helen MP. Nutrition And Metabolism $2^{\text {nd }}$ Ed. UK: Wiley-Blackwell 2011. p 247-283(12).

19. Nugraheni SA. Penatalaksanaan Diet pada Penyandang Autis. Badan Penerbit Universitas Diponegoro. 2009

20. Sofia AD. Kepatuhan orang tua dalam menerapkan terapi diet gluten free casein free pada anak penyandang autisme di yayasan pelita hafizh dan SLBN Cileunyi Bandung. Bandung: Universitas Padjajaran. 2012

21. William PG, Dalrymple N, Neal J. Eating habits of children with autism. Pediatr Nurs 2000; 26: 259-264

22. Handayani Maulina, Herini ES, Takada Santoshi. Eating behaviour of autistic children. Nurse Media Journal of Nursing 2012.281-294

23. Rahmawati Fika. Pengetahuan gizi, sikap, perilaku makan, dan asupan kalsium pada siswi SMA. [skripsi]. Semarang. Ilmu Gizi UNDIP. 2009

24. Ratnawati Hana. Leaky gut sebagai penyebab gangguan gastrointestinal pada ASD. JKM 2003. Vol. 2 No. 2

25. MacDonald Megan, Esposito Phil, Ulrich Dale. The physical activity patterns of children with autism. BioMed Central Research Notes 2011; 4:422

26. Cannell JJ. Autism and Vitamin D. Medical Hypotheses 2007; 08. 016 